\title{
A COHERENT MODEL OF DCF VALUATION
}

\author{
Wiktor Patena ${ }^{1}$
}

\begin{abstract}
Business valuation through $D C F$ is recognized as one of the most popular valuation approaches. DCF valuation models, however, have become extremely complex. Modeling requires plenty of input data to be processed, the process is done in many stages, and the data obtained on each of the stages may be interrelated. The process then is not simply a chain of tasks. The modern models work via sophisticated mechanisms of loops being triggered whenever a new piece of information is revealed and the whole model needs updating. Technically speaking, in the spreadsheets environment, this may only be done with the use of iterations. The valuation model should also be subjected to the sensitivity analysis, which is able to quantify the impact of every single assumption made on the final company value. The analysis points out the set of critical assumptions, which have the major impact on the calculated company's value. Apart from quantifying the impact of the assumptions, the analysis runs qualitative checks on the assumptions assessing the robustness of the arguments standing behind the critical factors for valuation. Consequently, the sensitivity analysis improves the objectivity of the model and mitigates the exposure for the possible results manipulation. The sensitivity analysis reveals its critical role in the valuation process and proves that it should be considered as the standard step in every DCF valuation.
\end{abstract}

Key words: company valuation, $D C F$, interactive financial planning system, sensitivity analysis, iterations.

\section{Model Coherence}

DCF valuation models have become extremely complex. Modeling requires plenty of input data to be processed, the process is done in many stages, and the data obtained on each of them may be interrelated. The process, however, is not simply a chain of tasks (Figure 1.1), where company input data (first column) and macroeconomic input data (second column) are processed in the system engine (third column). The modern models work via sophisticated mechanisms of loops being triggered whenever a new piece of information is revealed and the whole model is constantly updated. Technically speaking, in the spreadsheets environment, this may only be done with the use of iterations.

The objective of this paper is to demonstrate the complexity of contemporary DCF valuation models, show the interrelations within the model and present one of the solutions for maintaining the integrity of the model - iterations.

The paper is structured as follows: first, the model for creating forecasts (interactive financial planning system), then DCF model based on iterations (interactive valuation system), and finally a model of developing sensitivity analysis are presented and discussed. We deal only with a few components of the model, the ones that are crucial from the model coherence point of view.

\footnotetext{
${ }^{1}$ Wiktor Patena, Ph.D. in Economics, Wyzsza Szkola Biznesu - National Louis University, ul. Zielona 27, 33-300 Nowy Sacz, Poland, e-mail: patena@wsb-nlu.edu.pl
} 
Figure 1.1. Stages of DCF valuation
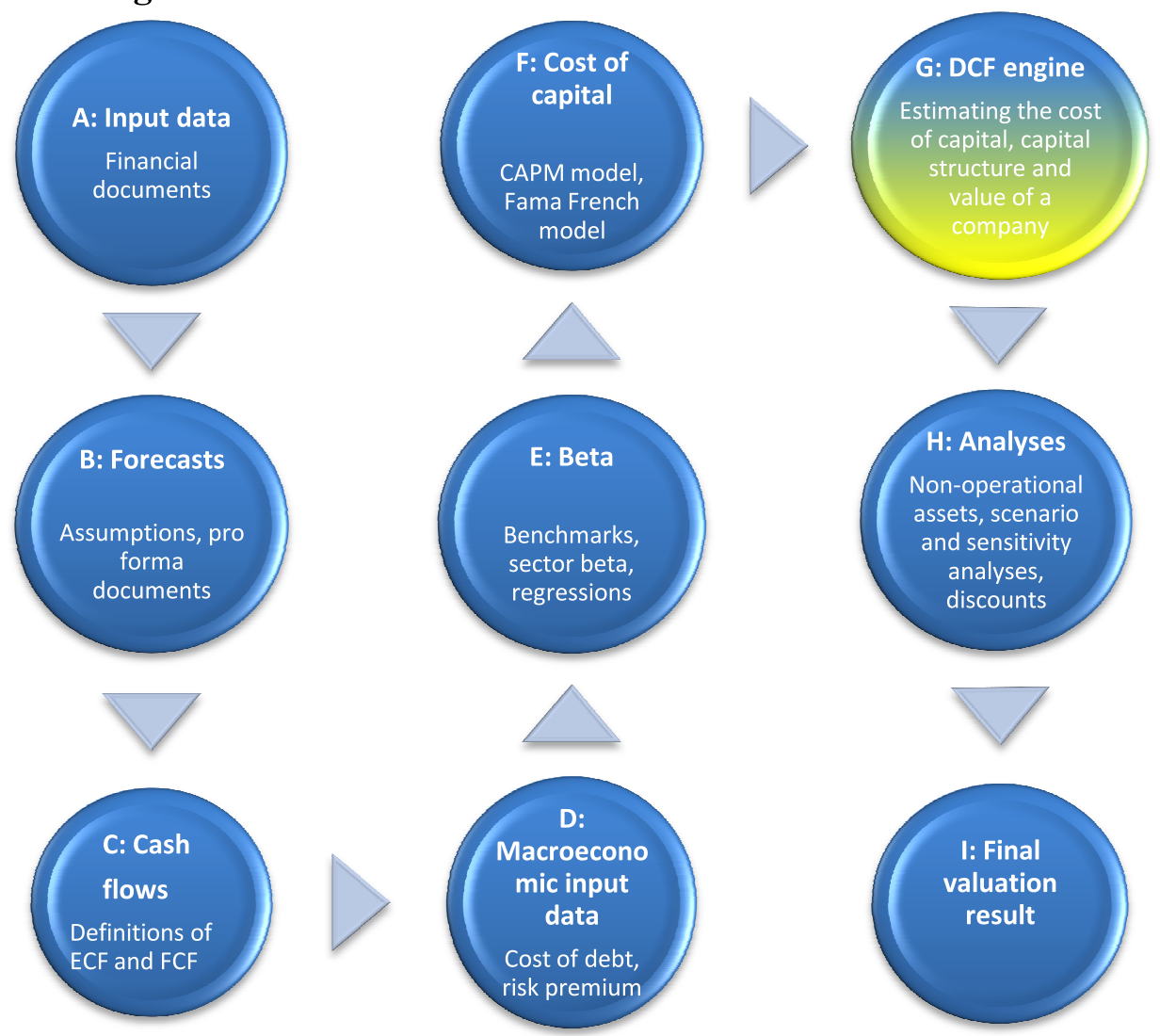

Source: Patena W. (2011). W poszukiwaniu wartości przedsiębiorstwa. Metody wyceny w praktyce. Kraków: Oficyna Wolters Kluwer Business, p. 296.

\section{Interactive financial planning system}

Financial forecasts (including all the pro forma documents: balance sheets, income statements, cash flow reports, ratio analysis) are typically built on the basis of interactive financial planning system - IFPS (Shim \& Siegel, 2006). The core components of the system are the formulae that refer to input data and, based on predefined assumptions, generate all the single entries of pro forma financial documents for a given period of time (typically 5-8 years). The whole set of net income and balance sheet equations is needed for that. A few simple examples of such formulae are presented in Figure 2. There, retained earnings must be linked to net income, interest income to the level of cash, interest payments to the level of debt, cash to the level of short term liabilities and short term debt is one of the balancing factors, to name just a few important links.

There are two approaches to build forecasts for a given company: bottom-up and topdown (Koller 2010). The starting point for any of them is analyzing macroeconomic data, a company's standing, plans designed by the company, and eventually estimating possible dynamics of sales, and then costs. Most of the entries in the balance sheet would depend on the sales dynamics. On the other hand, the main balance sheet entries may also depend on the assumptions related to turnover ratio - it is rational to assume that these should not change as long as the company stays in the same industry. The forecasts cannot ignore the fact that some industries are cyclical. It also must be decided whether the forecast is done with nominal or real prices. These issues, however, go beyond the main topic of the paper. 
Figure 2.1. Formulae for the IFPS

Retained earnings ${ }^{\mathrm{t}}=\mathrm{RE}^{\mathrm{t}-1}+$ net income ${ }^{\mathrm{t}} *$ plowback ratio

Net income ${ }^{\mathrm{t}}=\max \left(\right.$ tax rate $\left.^{*} \mathrm{EBT}^{\mathrm{t}}, 0\right)$

Interest income ${ }^{t}=$ interest rate on deposits ${ }^{t} *$ (cash and cash equivalents)

Interest payment ${ }^{t}=$ interest rate on loans ${ }^{t} *(\mathrm{debt})$

$\operatorname{Cash}^{\mathrm{t}}=\max \left(10 \% *\right.$ short term liabilities ${ }^{\mathrm{t}-1}$, total liabilities - fixed assets - inventory $-\mathrm{AR}-$ short term investment - pre paid expenses)

Source: author's elaboration

We tend to analyze only a technical aspect of forecasting. The key issue in financial modeling is balancing assets and liabilities. This is usually done with a debt-as-a-plug approach, meaning that any imbalance between assets and liabilities resulting from previously made and implemented assumptions finds its destination in the short-term debt entry. The formula below represents the concept which however is too complicated to be presented in a descriptive form (H cells refer to time $t$, and $\mathrm{G}$ cells to time $t-1$ ).

Figure 2.2. Formula for debt as a plug

Short term debt ${ }^{\mathrm{t}}=\mathrm{IF}\left(\left(\mathrm{H} 4^{\mathrm{t}}+\mathrm{H} 67^{\mathrm{t}}+\mathrm{H} 31^{\mathrm{t}}+\mathrm{H} 37^{\mathrm{t}}+\mathrm{H} 66^{\mathrm{t}}+\mathrm{H} 52^{\mathrm{t}}+\mathrm{H} 57^{\mathrm{t}}+0.1^{*} \mathrm{G} 100^{\mathrm{t}-1}-\mathrm{H} 73-\mathrm{H} 85-\mathrm{H} 93-\right.\right.$ $\mathrm{H} 101-\mathrm{H} 118-\mathrm{H} 119(\mathrm{H} 108+\mathrm{H} 109+\mathrm{H} 110+\mathrm{H} 113+\mathrm{H} 114+\mathrm{H} 115+\mathrm{H} 116+\mathrm{H} 117))>0$; $(\mathrm{H} 4+\mathrm{H} 67+\mathrm{H} 31+\mathrm{H} 37+\mathrm{H} 66+\mathrm{H} 52+\mathrm{H} 57+0.1 * \mathrm{G} 100-\mathrm{H} 73-\mathrm{H} 85-\mathrm{H} 93-\mathrm{H} 101-\mathrm{H} 118-\mathrm{H} 119-$ $(\mathrm{H} 108+\mathrm{H} 109+\mathrm{H} 110+\mathrm{H} 113+\mathrm{H} 114+\mathrm{H} 115+\mathrm{H} 116+\mathrm{H} 117)) ; 0)$

Source: author's elaboration

Debt (short term debt in the example above) is a plug - it changes automatically whenever assets exceed liabilities. Similarly, cash is a plug in the assets - the level of cash is kept at least on the level that is operationally justified, but it changes whenever liabilities exceed assets.

The model creates a coherent system of financial planning. A change of a single parameter is observable, one can easily create hypothetical scenarios and simulations with changed input data. The forecast is done in stages described in Figure 4. What is most important, however, is that this stage of company valuation is linked with the other stages. For example, the cost of debt that is used to calculate the interest payments affects the net income of the company. At the same time the very same cost of debt is a part of WACC formula that is used to calculate the value of the company and equity. Thus, each change in the interest rate will, in sequence, change the value of net income, WACC, capital structure and the value of equity. 
Figure 2.3. Stages of income statement and balance sheet forecasting

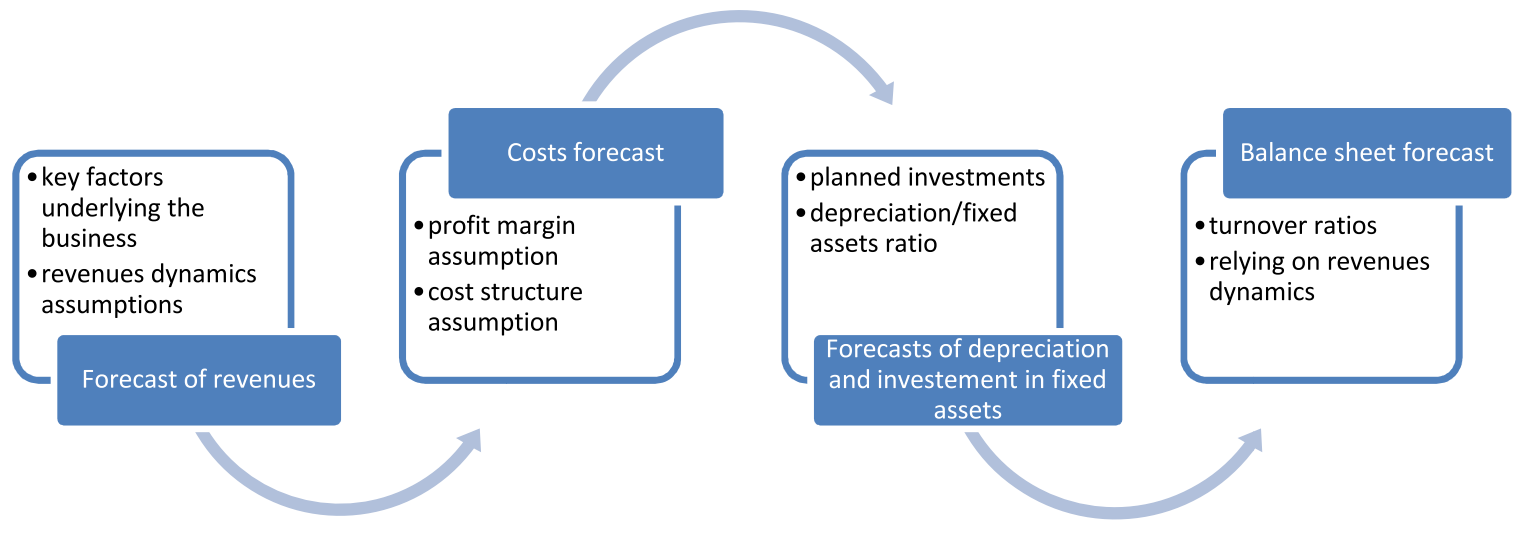

Source: author's elaboration

\section{Iteration-based DCF model}

When using a DCF model for company valuation one has to agree that estimating its value without looking into the future is impossible. The value of a company depends on cash flows that the company may generate in the future. The problem we are facing is then to:

- estimate future cash flows

- determine a discount factor - cost of capital.

The basic notion of the DCF method can be introduced with the following valuation formula.

$$
V_{0}=\frac{C F_{1}}{(1+k)^{1}}+\frac{C F_{2}}{(1+k)^{2}}+\ldots
$$

This is how the company's value is determined: certain cash flows are discounted with the cost of capital. There are three components involved: cash flows, cost of capital and the model (or the engine, technically speaking) explaining how the first two are related and eventually put together into a coherent system (Kruschwitz \& Loffler 2006).

Once we have financial documents pro forma, we can calculate the free cash flows. There are two basic valuation methods, corresponding to two kinds of cash flows: ECF (equity cash flow - cash flow available for shareholders only) and FCF (firm cash flow - cash flow available for both shareholders and debt holders). The methods are called FTE (flow to equity) and FTF (flow to firm) respectively (Capinski 2008, Fernandez 2005). Whichever of the two methods is used and even if the company model is simplified to being a perpetuity, certain technical problems are bound to appear (the points below exemplify the FTF approach).

1. One has to know the cost of capital WACC (and both its components: cost of debt and cost of equity) in order to calculate the value of a company.

2. One has to know the capital structure, that is the value of debt and equity, in order to calculate the cost of capital (cost of equity or WACC).

3. One has to know the value of interest payments, which is the value of debt, in order to calculate cash flows.

The problems create a logical loop: step 1 needs step 2, but step 2 requires step 1 and 3. The issue seems technical, but as a matter of fact it is a profound shift in the way the value can be found. An analytical solution to the problem is fairly straightforward (in case of 
perpetuities): we are facing the following system of equations, where $V$ is the value of a company and $W A C C$ the cost of capital.

\section{Figure 3.1.. System of equations - analytical solution}

$$
\left\{\begin{array}{c}
V=\frac{F C F}{W A C C} \\
W A C C=k_{D} \times(1-T) \times \frac{D}{V}+k_{E} \times \frac{V-D}{V}
\end{array} .\right.
$$

Source: author's elaboration

The problem can also be solved numerically. We should enter the formulae for WACC and $\mathrm{V}$ in the appropriate cells in Excel, replacing the missing values of WACC and V with the (incomplete) results obtained in the cells. The loop is then complete and the final results are correct. The loop will work on one condition: a feedback loop must be activated in Excel (go to Excel Options/Formulae, tick Manual Calculation and Iteration boxes). The loops can be triggered by pressing the F9 key.

In a real life case, however, when one has to deal with numerous parameters and time periods, a numerical solution seems to be the only feasible approach. For example, in order to find the value $V$ (for a given year $t$ ), one needs to know the values of $W A C C$, next $E$, and then $k_{E}$. It is impossible to calculate $W A C C$ without $V$ (the one we look for), and $E$ without $k_{E}$. There appears a chain of logical loops and formulae (Figure 6) that become so integrated that the information between cash flows and cost of capital moves freely. The cost of capital "tracks" the capital structure and changes accordingly, while $E C F$ is a reflection of future profits and also the level of debt in the company (Figure 7). The valuation is recursive, going backwards in time. Explaining the methodological aspects of the model is beyond the scope of the paper - we follow the theory developed by M. Capinski (Capinski 2008).

In general, the recursive method of company valuation that has been shown overcomes a fundamental problem that is often ignored by many other methods: the fact that the cost of capital depends on the financial structure. It creates additional technical problems in a form of a logical loop but this was also remedied. To conclude, calculating the value of a company without using iterations is tantamount to applying the wrong weights to $W A C C$ and leads to an inner contradiction (Ibragimov 2008). 


\section{Figure 3.2. Interlinked equations}

$V_{t-1}=\frac{V_{t}+F C F_{t-1}}{\left(1+W A C C_{t-1}\right)}$.

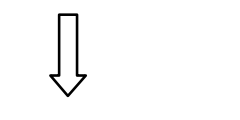

$W A C C_{t-1}=k_{D} \times(1-T) \times \frac{D_{t-1}}{\left(E_{t-1}+D_{t-1}\right)}+k_{E, t-1} \times \frac{E_{t-1}}{\left(E_{t-1}+D_{t-1}\right)}$

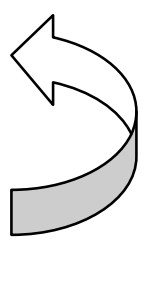

$\sqrt{b}$

$E_{t-1}=\frac{E_{t}+C F_{t-1}}{\left(1+k_{E, t-1}\right)}$
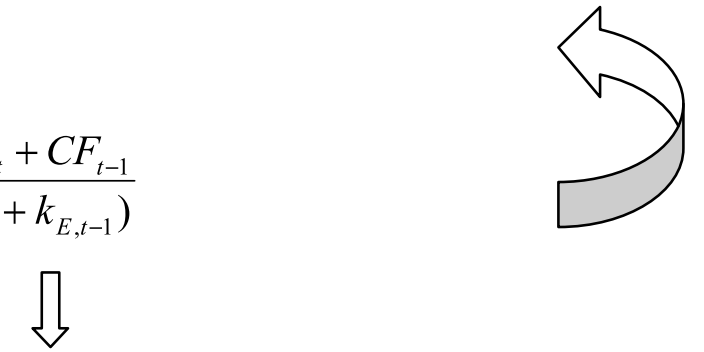

$k_{E, t-1}=k_{U}+\left(k_{U}-k_{D}\right) \times \frac{D_{t-1} \times(1-T)}{E_{t-1}}$.

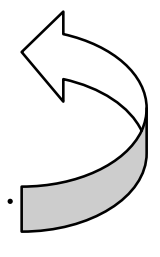

Source: author's elaboration

What is more, iterations enable creating a coherent valuation system. In Figure 3.3. (engine of the model) one can see how the formulae are linked. To take just one example, calculating E (FTE) for 2012 requires ECF (preceded by cash flow calculations in a separate spreadsheet and pro forma spreadsheets) for the same year, the value of equity for the previous period and the cost of equity which in turn needs $\mathrm{k}_{\mathrm{U}}$, capital structure (links to the value of $\mathrm{D}$ and $\mathrm{E}$ ), tax rate and many more. The loops work until the model is in equilibrium. The final touch is to provide the current cost of equity (10.27\% in Figure 3.3.). Then the model is complete and generates the current fair value of equity $(\mathrm{E}=8904140$ in Figure 3.3.). 
Figure 3.3. System of equations - numerical solution (part of the DCF engine)

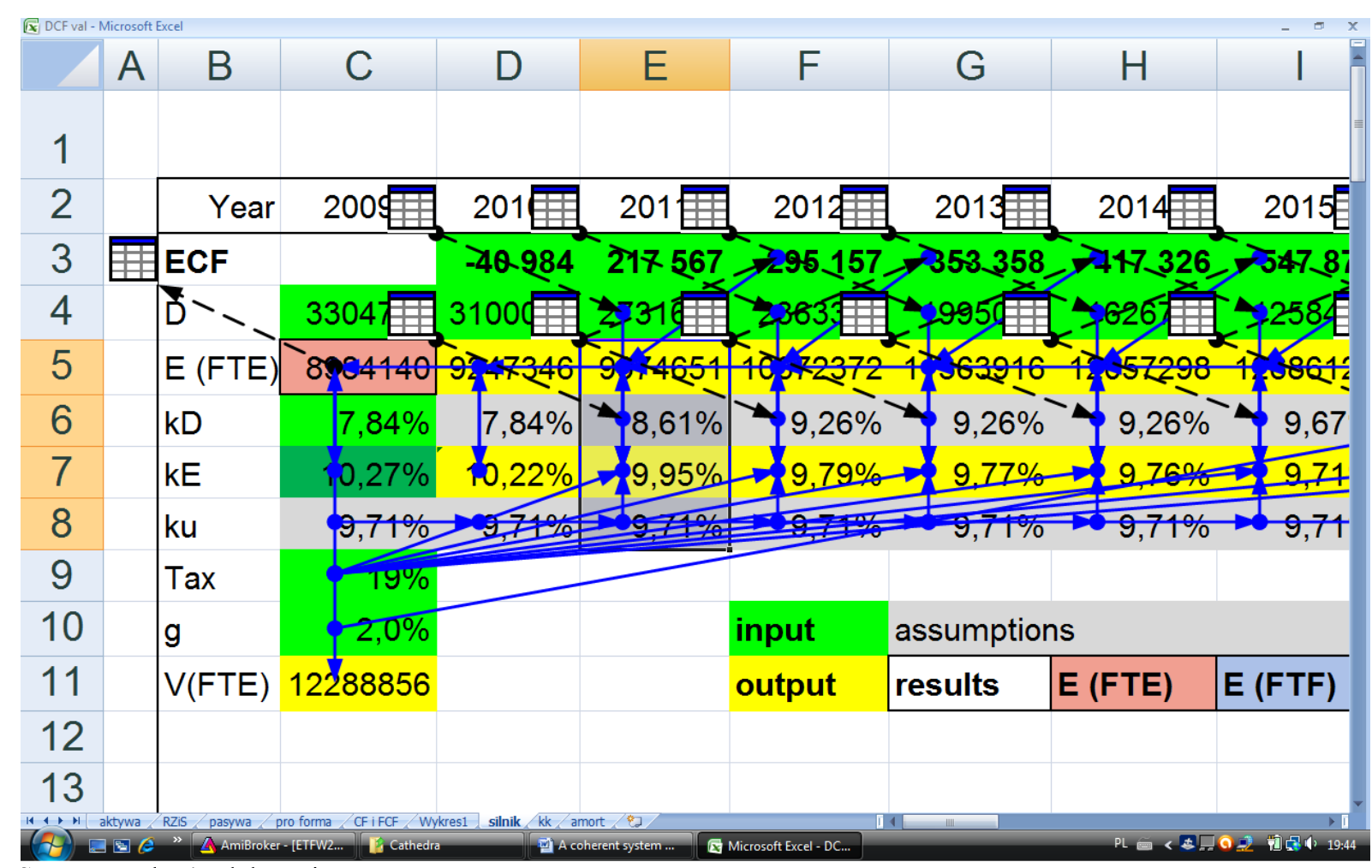

Source: author's elaboration

\section{Sensitivity analysis}

Sensitivity analysis is a sine qua non component of any DCF valuation. It enables:

1. identifying the assumptions that are critical in terms of the valuation model.

2. Avoiding subjectivity and manipulation by verifying the validity of the key assumptions.

In other words, this is the part of the valuation in which one tests the model's reliability and objectivity. The critical moment in DCF valuation is building pro forma financial documents that are based on a set of assumptions. This has much to do with understanding the nature of the business and then identifying the crucial variables that are value drivers of the company (Koller 2010). At the end of the valuation process one needs to verify how sensitive the model is to changes in the set of assumptions. The set is typically composed with dozens of variables, some of which refer to the valuation theory or macroeconomic situation and are not included in the sensitivity analysis (e.g. risk free rate, risk premium). The others are relevant from the sensitivity analysis point of view and typically include:

- Dynamics of revenues in the given years of the forecast,

- Wages in relation to operational costs,

- Growth factor g,

- Tax rate,

- $\beta$ factor

- Cost of equity

- Cost of debt,

- Operational costs in relation to revenues,

- Depreciation in relation to fixed assets, 
- $\mathrm{AR}$ and $\mathrm{AP}$ in relation to revenues,

- Inventory in relation to revenues,

- Reinvestment ratio.

Technically speaking, one can make the sensitivity analysis using the data tables feature that is available in some spreadsheets. Arranging all the data properly one can observe how the final value varies if you modify the chosen variables. You can make a single variable sensitivity analysis by selecting only one parameter, but the two variable tables are much more useful - you calculate the changes in the final value based on two parameters. Below, we present examples of the sensitivity analysis for two sets of parameters. Figure 8 shows an example of the assumed changes in the revenues dynamics: namely $-5 \%$ in the years 1-2 (columns) and $0 \%$ in the years 3-5 (rows). In Figures 4.1-3 one can watch the values resulting from the changes (originally 29.95).

Figure 4.1. Sensitivity analysis - change in revenues $v$ change in the value of company

\begin{tabular}{|r|rrrrrrrrrrrr|}
\hline \multicolumn{10}{|c|}{ \% change in revenue in the years } & $\mathbf{1 - 2}$ (columns) and 3-5 (rows) \\
\hline $\mathbf{2 9 . 9 5}$ & $-5 \%$ & $-4 \%$ & $-3 \%$ & $-2 \%$ & $-1 \%$ & $0 \%$ & $1 \%$ & $2 \%$ & $3 \%$ & $4 \%$ & $5 \%$ \\
\hline $0 \%$ & 30.11 & 30.56 & 31.00 & 31.45 & 31.90 & 32.34 & 32.79 & 33.23 & 33.68 & 34.12 & 34.57 \\
$-1 \%$ & 29.66 & 30.10 & 30,54 & 30,98 & 31,42 & 31,86 & 32,31 & 32,75 & 33,19 & 33,63 & 34,07 \\
$-2 \%$ & 29,20 & 29,64 & 30,08 & 30,51 & 30,95 & 31,39 & 31,82 & 32,26 & 32,70 & 33,13 & 33,57 \\
$-\mathbf{- 3 \%}$ & 28,75 & 29,18 & 29,61 & 30,04 & 30,48 & 30,91 & 31,34 & 31,77 & 32,21 & 32,64 & 33,07 \\
$-4 \%$ & 28,29 & 28,72 & 29,15 & 29,58 & 30,00 & 30,43 & 30,86 & 31,29 & 31,71 & 32,14 & 32,57 \\
$-\mathbf{- 5 \%}$ & 27,84 & 28,26 & 28,68 & 29,11 & 29,53 & 29,95 & 30,38 & 30,80 & 31,22 & 31,65 & 32,07 \\
$-6 \%$ & 27,38 & 27,80 & 28,22 & 28,64 & 29,06 & 29,48 & 29,89 & 30,31 & 30,73 & 31,15 & 31,57 \\
$-\mathbf{- 7 \%}$ & 26,93 & 27,34 & 27,75 & 28,17 & 28,58 & 29,00 & 29,41 & 29,83 & 30,24 & 30,66 & 31,07 \\
$-\mathbf{- 8 \%}$ & 26,47 & 26,88 & 27,29 & 27,70 & 28,11 & 28,52 & 28,93 & 29,34 & 29,75 & 30,16 & 30,57 \\
$-\mathbf{- 9 \%}$ & 26,02 & 26,42 & 26,83 & 27,23 & 27,64 & 28,04 & 28,45 & 28,85 & 29,26 & 29,66 & 30,07 \\
$-10 \%$ & 25,56 & 25,96 & 26,36 & 26,76 & 27,16 & 27,57 & 27,97 & 28,37 & 28,77 & 29,17 & 29,57 \\
\hline
\end{tabular}

Source: Patena W. (2011). W poszukiwaniu wartości przedsiębiorstwa. Metody wyceny w praktyce. Kraków: Oficyna Wolters Kluwer Business, p. 296. 
Figure 4.2. Sensitivity analysis - change in revenues v change in the value of company $(\%)$

\begin{tabular}{|r|rrrrrrrrrrr|}
\hline \multicolumn{7}{|c}{$\%$ change in revenue in the years 1-2 (columns) and 3-5 (rows) } \\
\hline $\mathbf{2 9 . 9 5}$ & $-5 \%$ & $-4 \%$ & $-3 \%$ & $-2 \%$ & $-1 \%$ & $0 \%$ & $1 \%$ & $2 \%$ & $3 \%$ & $4 \%$ & $5 \%$ \\
\hline $0 \%$ & $0.53 \%$ & $2.04 \%$ & $3.51 \%$ & $5.01 \%$ & $6.51 \%$ & $7.98 \%$ & $9.48 \%$ & $10.95 \%$ & $12.45 \%$ & $13.92 \%$ & $15.43 \%$ \\
$-1 \%$ & $-0.97 \%$ & $0.50 \%$ & $1.97 \%$ & $3.44 \%$ & $4.91 \%$ & $6.38 \%$ & $7.88 \%$ & $9.35 \%$ & $10.82 \%$ & $12.29 \%$ & $13.76 \%$ \\
$-2 \%$ & $-2.50 \%$ & $-1.04 \%$ & $0.43 \%$ & $1.87 \%$ & $3.34 \%$ & $4.81 \%$ & $6.24 \%$ & $7.71 \%$ & $9.18 \%$ & $10.62 \%$ & $12.09 \%$ \\
$-3 \%$ & $-4.01 \%$ & $-2.57 \%$ & $-1.14 \%$ & $0.30 \%$ & $1.77 \%$ & $3.21 \%$ & $4.64 \%$ & $6.08 \%$ & $7.55 \%$ & $8.98 \%$ & $10.42 \%$ \\
$-4 \%$ & $-5.54 \%$ & $-4.11 \%$ & $-2.67 \%$ & $-1.24 \%$ & $0.17 \%$ & $1.60 \%$ & $3.04 \%$ & $4.47 \%$ & $5.88 \%$ & $7.31 \%$ & $8.75 \%$ \\
$-5 \%$ & $-7.05 \%$ & $-5.64 \%$ & $-4.24 \%$ & $-2.80 \%$ & $-1.40 \%$ & $0.00 \%$ & $1.44 \%$ & $2.84 \%$ & $4.24 \%$ & $5.68 \%$ & $7.08 \%$ \\
$-6 \%$ & $-8.58 \%$ & $-7.18 \%$ & $-5.78 \%$ & $-4.37 \%$ & $-2.97 \%$ & $-1.57 \%$ & $-0.20 \%$ & $1.20 \%$ & $2.60 \%$ & $4.01 \%$ & $5.41 \%$ \\
$-7 \%$ & $-10.08 \%$ & $-8.71 \%$ & $-7.35 \%$ & $-5.94 \%$ & $-4.57 \%$ & $-3.17 \%$ & $-1.80 \%$ & $-0.40 \%$ & $0.97 \%$ & $2.37 \%$ & $3.74 \%$ \\
$-8 \%$ & $-11.62 \%$ & $-10.25 \%$ & $-8.88 \%$ & $-7.51 \%$ & $-6.14 \%$ & $-4.77 \%$ & $-3.41 \%$ & $-2.04 \%$ & $-0.67 \%$ & $0.70 \%$ & $2.07 \%$ \\
$-9 \%$ & $-13.12 \%$ & $-11.79 \%$ & $-10.42 \%$ & $-9.08 \%$ & $-7.71 \%$ & $-6.38 \%$ & $-5.01 \%$ & $-3.67 \%$ & $-2.30 \%$ & $-0.97 \%$ & $0.40 \%$ \\
$-10 \%$ & $-14.66 \%$ & $-13.32 \%$ & $-11.99 \%$ & $-10.65 \%$ & $-9.32 \%$ & $-7.95 \%$ & $-6.61 \%$ & $-5.28 \%$ & $-3.94 \%$ & $-2.60 \%$ & $-1.27 \%$ \\
\hline
\end{tabular}

Source: Patena W. (2011). W poszukiwaniu wartości przedsiębiorstwa. Metody wyceny w praktyce. Kraków: Oficyna Wolters Kluwer Business, p. 296.

Figure 4.3. Sensitivity analysis - change in revenues $v$ change in the value of company (\%)

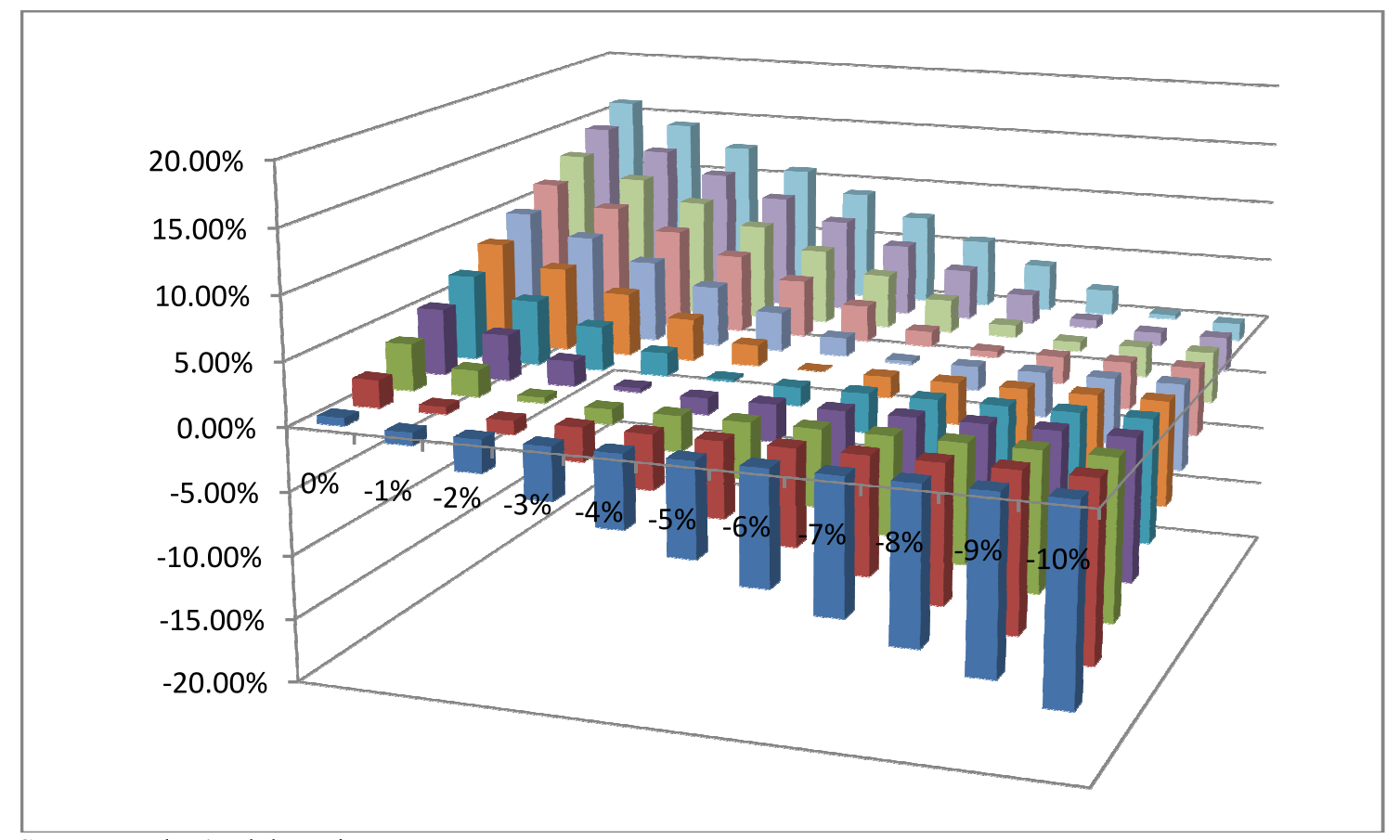

Source: author's elaboration

Another example shows how the relation of accounts receivables (AR) with regard to revenues (originally 5.3\%) and inventory with regard to revenues (originally $11 \%$ ) affect the final value of company (originally 29.40). The original values are based on the analysis of historical data, median or the average. The analysis shows that the change of the parameters has a weak effect on the final value: the change of 1 percentage point results in a $1.8 \%$ change of the final value. To conclude, the model is not very sensitive to changes in these parameters. 
Figure 4.4. Sensitivity analysis - change in AR and inventory $v$ change in the value of company

\begin{tabular}{|r|rrrrrrrrrrr|}
\hline \multicolumn{10}{|c|}{ AR (columns) and inventory (rows) as \% of revenues } \\
\hline $\mathbf{2 9 . 4 0}$ & 0.09 & 0.1 & 0.11 & 0.12 & 0.13 & 0.14 & 0.15 & 0.16 & 0.17 & 0.18 & 0.19 \\
\hline 0 & 33.41 & 32.86 & 32.31 & 31.76 & 31.21 & 30.67 & 30.12 & 29.57 & 29.02 & 28.47 & 27.92 \\
0.003 & 33.24 & 32.70 & 32.15 & 31.60 & 31.05 & 30.50 & 29.95 & 29.40 & 28.86 & 28.31 & 27.76 \\
0.013 & 32.70 & 32.15 & 31.60 & 31.05 & 30.50 & 29.95 & 29.40 & 28.86 & 28.31 & 27.76 & 27.21 \\
0.023 & 32.15 & 31.60 & 31.05 & 30.50 & 29.95 & 29.40 & 28.86 & 28.31 & 27.76 & 27.21 & 26.66 \\
0.033 & 31.60 & 31.05 & 30.50 & 29.95 & 29.40 & 28.86 & 28.31 & 27.76 & 27.21 & 26.66 & 26.11 \\
0.043 & 31.05 & 30.50 & 29.95 & 29.40 & 28.86 & 28.31 & 27.76 & 27.21 & 26.66 & 26.11 & 25.57 \\
0.053 & 30.50 & 29.95 & 29.40 & 28.86 & 28.31 & 27.76 & 27.21 & 26.66 & 26.11 & 25.57 & 25.02 \\
0.063 & 29.95 & 29.40 & 28.86 & 28.31 & 27.76 & 27.21 & 26.66 & 26.11 & 25.57 & 25.02 & 24.47 \\
\hline
\end{tabular}

Source: author's elaboration

Figure 4.5. Sensitivity analysis - change in AR and inventory $v$ change in the value of company $(\%)$

\begin{tabular}{|r|rrrrrrrrrrrr|}
\hline \multicolumn{10}{|c|}{ AR (columns) and inventory (rows) as \% } & of revenues \\
\hline $\mathbf{2 9 . 4 0}$ & 0.09 & 0.1 & 0.11 & 0.12 & 0.13 & 0.14 & 0.15 & 0.16 & 0.17 & 0.18 & 0.19 \\
\hline 0 & $13.64 \%$ & $11.77 \%$ & $9.90 \%$ & $8.03 \%$ & $6.16 \%$ & $4.32 \%$ & $2.45 \%$ & $0.58 \%$ & $-1.29 \%$ & $-3.16 \%$ & $-5.03 \%$ \\
0.003 & $13.06 \%$ & $11.22 \%$ & $9.35 \%$ & $7.48 \%$ & $5.61 \%$ & $3.74 \%$ & $1.87 \%$ & $0.00 \%$ & $-1.84 \%$ & $-3.71 \%$ & $-5.58 \%$ \\
0.013 & $11.22 \%$ & $9.35 \%$ & $7.48 \%$ & $5.61 \%$ & $3.74 \%$ & $1.87 \%$ & $0.00 \%$ & $-1.84 \%$ & $-3.71 \%$ & $-5.58 \%$ & $-7.45 \%$ \\
0.023 & $9.35 \%$ & $7.48 \%$ & $5.61 \%$ & $3.74 \%$ & $1.87 \%$ & $0.00 \%$ & $-1.84 \%$ & $-3.71 \%$ & $-5.58 \%$ & $-7.45 \%$ & $-9.32 \%$ \\
0.033 & $7.48 \%$ & $5.61 \%$ & $3.74 \%$ & $1.87 \%$ & $0.00 \%$ & $-1.84 \%$ & $-3.71 \%$ & $-5.58 \%$ & $-7.45 \%$ & $-9.32 \%$ & $-11.19 \%$ \\
0.043 & $5.61 \%$ & $3.74 \%$ & $1.87 \%$ & $0.00 \%$ & $-1.84 \%$ & $-3.71 \%$ & $-5.58 \%$ & $-7.45 \%$ & $-9.32 \%$ & $-11.19 \%$ & $-13.03 \%$ \\
0.053 & $3.74 \%$ & $1.87 \%$ & $0.00 \%$ & $-1.84 \%$ & $-3.71 \%$ & $-5.58 \%$ & $-7.45 \%$ & $-9.32 \%$ & $-11.19 \%$ & $-13.03 \%$ & $-14.90 \%$ \\
0.063 & $1.87 \%$ & $0.00 \%$ & $-1.84 \%$ & $-3.71 \%$ & $-5.58 \%$ & $-7.45 \%$ & $-9.32 \%$ & $-11.19 \%$ & $-13.03 \%$ & $-14.90 \%$ & $-16.77 \%$ \\
\hline
\end{tabular}

Source: author's elaboration

The sensitivity analysis is definitely recommended as a summary of any DCF valuation. The DCF models are based on many quantitative data but also dozens of assumptions whose validity needs to be double checked. The final report of the sensitivity analysis (Figure 4.6.) reveals which assumptions are prone to miscalculations and may have to be revised. The summary confirms the obvious truth that the effect of the change in a given parameter is related to its utility. No wonder that the assumption referring to a short period of time had smaller effect than those referring to longer periods (including those affecting the residual value). Another conclusion is that the assumptions related to the structure of the income statement are very sensitive to changes. As shown in Figure 4.6., the 1\% change of COGS results in over $21 \%$ change in the final value. 
Figure 4.6. Sensitivity analysis - summary (example)

\begin{tabular}{|l|c|c|}
\hline \multicolumn{1}{|c|}{ Assumption } & \multicolumn{2}{c|}{ Change of the COMPANY VALUE(\%) } \\
\hline & $\mathbf{+ 1} \mathbf{p . p .}$ & $\mathbf{- 1} \mathbf{p .} \mathbf{p .}$ \\
\hline Revenue growth in the years 1-2 & $1.60 \%$ & $1.57 \%$ \\
\hline Revenue growth in the years 3-5 & $1.40 \%$ & $1.44 \%$ \\
\hline Growth factor g & $24.12 \%$ & $14.36 \%$ \\
\hline COGS as \% of revenues & $21.12 \%$ & $21.15 \%$ \\
\hline Depreciation as \% of fixed assets & $2.78 \%$ & $3.06 \%$ \\
\hline AR as \% of revenues & $1.87 \%$ & $1.84 \%$ \\
\hline Inventory as \% of revenues & $1.87 \%$ & $1.84 \%$ \\
\hline AP as \% revenues & $0.00 \%$ & $3.71 \%$ \\
\hline WACC in the years $1-2$ & $0.17 \%$ & $0.17 \%$ \\
\hline WACC in the years 3-5 & $17.99 \%$ & $28.13 \%$ \\
\hline
\end{tabular}

Source: author's elaboration

In general, a sensitivity analysis provides a picture of relative sensitivity of the model to certain changes. Some of them are justified and predictable, others may raise doubts and lead to model revisions. In particular, one should pay special attention to those assumption whose influence on the final value seems great and which were accepted as a result of not a quantitative analysis but based on data which are hard to verify. The DCF valuation model should then work in a circle: once the value is generated, the sensitivity analysis shows whether the assumptions are credible. If not, they are revised and the valuation is generated again, as shown in Figure 4.7.

Figure 4.7. Coherent model of DCF valuation

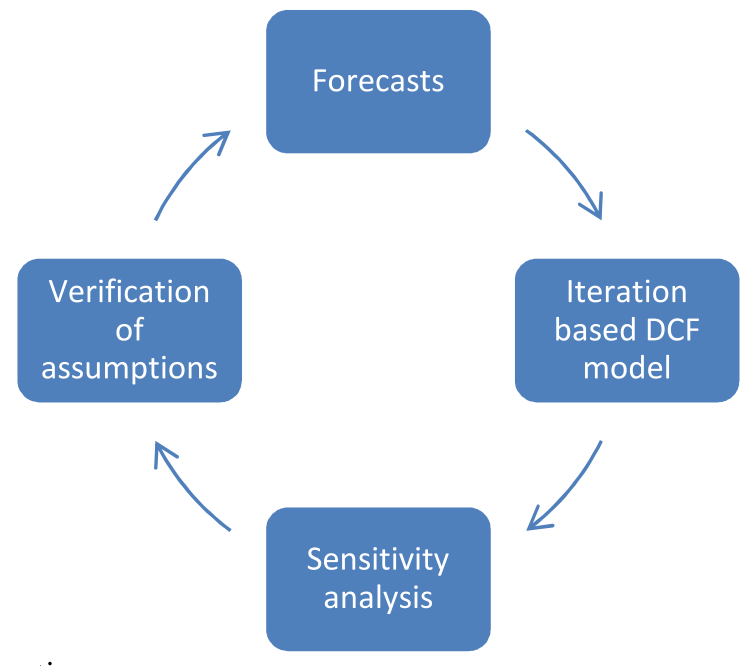

Source: author's elaboration

\section{Conclusions}

DCF valuation models have become extremely complex. Still, for the credibility of the valuation process, it is essential that the model is coherent and all the parts of the process are well integrated. Generating the final value does not finish the valuation process. With models involving dozens of variables, the real challenge is to understand the model and identify the assumptions that are critical for the valuation process.

We emphasize three parts of the valuation process that are indispensible for the integrity of DCF valuation. First, the model for creating forecasts needs to be interactive and 
the generated pro forma financial documents must be properly linked with external (macroeconomic) and internal (historical) data. Second, the modern DCF models work via sophisticated mechanisms of loops being triggered whenever a new piece of information is revealed and the whole model needs updating. In the spreadsheets environment, this may be done with the use of iterations. The method of company valuation based on iterations overcomes a fundamental problem that is often ignored by many other methods: the fact that the cost of capital should depend on the financial structure. Finally, the valuation model should be subjected to the sensitivity analysis, which is able to quantify the impact of every single assumption made on the final company value. The analysis points out the set of critical assumptions which have the major impact on the calculated company's value. Apart from quantifying the impact of the assumptions, the analysis runs qualitative checks on the assumptions assessing the robustness of the arguments standing behind the critical factors for valuation. The model gains a higher level of objectivity since it is no longer pegged to the assumptions for good. These may be revised whenever the model seems oversensitive to some of them. Consequently, the sensitivity analysis improves the objectivity of the model and mitigates the exposure for the possible results of manipulation. The sensitivity analysis reveals its critical role in the valuation process and proves that it should be considered as a standard step in every DCF valuation.

\section{References:}

Benninga S., Sarig O. (1996). Corporate Finance: A Valuation Approach. Boston: McGrawHill.

Brealey R.A., Meyers S.C. (2003). Principles of Corporate Finance. Boston: McGrow Hill.

Capiński M., Patena W. (2008). Company Valuation - Value, Structure, Risk. Hof: University Of Applied Sciences.

Capiński M. (2005). A New Method of DCF Valuation. Nowy Sacz Academic Review. $2005 / 2$

Capiński M., Patena W. (2006). Real Options - Realistic Valuation. Journal of Business and Society. 2006/3

Copeland T.E., Koller T., Murrin J. (2000). Valuation. Measuring and Managing the Value of Companies. New York: John Wiley and Sons.

Damodaran A. (2002). Investment Valuation. New York: John Wiley \& Sons.

Damodaran A. (2001). The Dark Side of Valuation. New York: John Wiley and Sons.

Fernandez P. (2002). Valuation and Shareholder Value Creation. San Diego: Academic Press.

Fernandez P., Bilan A. (2007). 110 Common Errors in Company Valuations. http://ssrn.com

Fernandez P. (2005). Financial Literature about Discounted Cash Flow Valuation. IESE Business School Working Paper No.606. http://ssrn.com

Fama E.F., French K.R. (1993). Common Risk Factors in the Returns on Stocks and Bonds. Journal of Financial Economics. 1993. No 33.

Ibragimov R. (2008). Errors in 110 Common Errors in Company Valuation. http://ssrn.com

Koller T., Goedhart M.. Wessels D. (2010). Valuation. Measuring and Managing the Value of Companies. McKinsley.

Kruschwitz L., Loffler A. (2006). Discounted Cash Flow - A Theory of the Valuation of Firms. Wiley Finance.

Shim J., Siegel J. (2006). Dyrektor finansowy. Kraków: Oficyna Ekonomiczna.

Vernimmen P. (2005). Corporate Finance. Theory and Practice. John Wiley \& Sons. 


\begin{abstract}
Abstrakt
Wycena przedsiębiorstw poprzez DCF jest uznawana za jedna z najbardziej popularnych metod wyceny. Modele wyceny DCF staty się jednak niezwykle skomplikowane. Modeling wymaga wiele danych wejściowych do przetworzenia, proces odbywa się w kilku etapach, a dane uzyskane w każdym z etapów moga być ze soba powiazane. Proces nie jest po prostu łańcuchem zadań. Nowoczesne modele pracy, poprzez zaawansowane mechanizmy pętli, jest uruchamiany zawsze, gdy nowa informacja się pojawia, $i$ caty model wymaga aktualizacji. Technicznie rzecz biorac, $w$ arkuszach kalkulacyjnych, może być dokonana analiza jedynie z zastosowaniem iteracji. Modele wyceny powinny być również poddane analizie wrażliwości, która jest w stanie obliczyć wpływ każdego założenia na ostateczna wartość firmy. Analiza wskazuje na zestaw kluczowych założeń, które maja duży wpływ na obliczona wartość firmy. Oprócz ilościowego określenia wpływu założen, analizy jakościowe prowadza kontrole założenia oceny niezawodności argumentów odpowiedzialne za kluczowe czynniki wyceny. W zwiąku z tym, analiza wrażliwości poprawia obiektywność modelu i zmniejsza narażenie na manipulowanie wynikami. Analiza wrażliwości pokazuje jej kluczowa rolę $w$ procesie wyceny $i$ udowadnia, że należy go traktować jako standardowy krok w wycenie DCF.
\end{abstract}

